\title{
Succession in subtidal macrofouling assemblages of a Patagonian harbour (Argentina, SW Atlantic)
}

\author{
Alicia Rico $\cdot$ Roxana Peralta $\cdot$ Juan López Gappa
}

Received: 7 April 2011 / Revised: 11 January 2012 / Accepted: 18 January 2012 / Published online: 2 February 2012

(C) Springer-Verlag and AWI 2012

\begin{abstract}
Subtidal fouling assemblages usually consist of short-lived organisms. Colonisation sequences on manmade structures may thus be greatly affected by the temporal and spatial variability of propagule supply. This study explores the influence of seasonality on succession in the macrofouling assemblage of a Patagonian harbour (Argentina, Southwest Atlantic). Replicated artificial substrata were suspended horizontally and sampled at quarterly intervals during 1 year. The influence of seasonality on 1-yearold assemblages was further analysed using additional sets of replicated panels submersed at different seasons and collected 1 year later. Upper surfaces were always dominated by ephemeral algae, while lower surfaces exhibited high coverage of filter-feeding invertebrates. Regardless of submersion length, species richness was significantly higher on lower than on upper surfaces. A significant interaction between orientation and submersion length was found for the Shannon diversity index, meaning that temporal changes in diversity depended on substratum orientation.
\end{abstract}

Communicated by Martin Thiel.

Electronic supplementary material The online version of this article (doi:10.1007/s10152-012-0293-4) contains supplementary material, which is available to authorized users.

A. Rico $\cdot$ R. Peralta

Departamento de Biología General,

Facultad de Ciencias Naturales,

Universidad Nacional de la Patagonia, Ciudad Universitaria,

Km 4, 9000 Comodoro Rivadavia,

Chubut, Argentina

J. López Gappa ( $\square)$

Museo Argentino de Ciencias Naturales, Angel Gallardo 470, C1405DJR Buenos Aires, Argentina

e-mail: lgappa@macn.gov.ar
On the lower surfaces, diversity reached a maximum after 9 months and then declined, mainly due to extensive dislodgment of two species of ascidians. On algal-dominated upper surfaces, differences in structure of annual assemblages were due to seasonal changes in the abundance of ephemeral algae. This study shows that constancy or variability of 1-year-old assemblages whose development began at different seasons depended greatly on the life history of the organisms that settled and managed to persist on both surfaces, which in turn depended on substratum orientation.

Keywords Macrofouling · Succession - Seasonality · Harbour · Patagonia · Argentina

\section{Introduction}

The concept of succession was originally introduced by terrestrial ecologists and implies directional and predictable changes in the colonisation of disturbed or new substrata which result in modifications of the physical environment (Connell and Slatyer 1977; reviewed in McCook 1994). In marine epifaunal assemblages, several studies evidenced interspecific mechanisms involving facilitation or inhibition (Sutherland and Karslon 1977; Dean and Hurd 1980; Turner 1983), as well as the occurrence of clear competitive hierarchies in space occupancy (Kay and Keough 1981). Other studies, however, showed that succession is far from predictable, as its course depends on factors such as random fluctuations in the recruitment of invertebrate larvae from the plankton (Underwood and Denley 1984; Gaines and Roughgarden 1985), the dynamics of offshore water masses (Farrell et al. 1991) and life history features of the interacting species (McCook 1994). 
Epifaunal colonisers at initial stages of succession usually are short-lived organisms (Sutherland and Karslon 1977). Thus, colonisation sequences may be greatly affected by the temporal and spatial variability of propagule supply (Osman 1977; Chalmer 1982; Cifuentes et al. 2010), determining the occurrence of multiple stable points (sensu Sutherland 1974). As recruitment is often highly seasonal (Turner and Todd 1993), the time of the year at which succession begins may exert a considerable influence on epifaunal community structure (Breitburg 1985). Effects of seasonality on succession, however, are not always evident, because establishing subtidal macrobenthic communities may converge to a similar structure regardless of the season at which they started (Cifuentes et al. 2010; Pacheco et al. 2010b, 2011).

In subtidal habitats, light and sedimentation interact with surface orientation to maintain clear differences in the composition of assemblages developed on upper and lower surfaces of hard substrata (Irving and Connell 2002; Stark 2008). Spirorbid polychaetes, bryozoans and compound ascidians often dominate on lower surfaces (Glasby and Connell 2001), while algae are conspicuous components on the upper surfaces (Irving and Connell 2002). Since filamentous algae usually have short life-cycles and high growth rates (Littler and Murray 1974; Steneck and Dethier 1994), the influence of seasonality on succession could be predicted to act in a different way on upper than on lower surfaces.

This study aimed to analyse the dynamics of the macrofouling assemblage of a Patagonian harbour in order to explore the role of seasonality and substratum orientation on succession. Based on the available information, we tested the hypothesis that the influence of seasonality on succession analysed at quarterly intervals and on 1-year-old assemblages initiated at different seasons would cause different responses (i.e., a significant spatio-temporal interaction) on upper than on lower surfaces.

\section{Materials and methods}

Study area

Comodoro Rivadavia harbour (Argentina, SW Atlantic) lies in the centre of San Jorge Gulf $\left(45^{\circ} 51^{\prime} 35^{\prime \prime} \mathrm{S}, 67^{\circ} 27^{\prime} 23^{\prime \prime} \mathrm{W}\right)$. Its physical environment was described in a previous study (Rico et al. 2010). Briefly, the range of sea surface temperatures is about $15^{\circ} \mathrm{C}$, with a maximum around $19^{\circ} \mathrm{C}$ in February (summer) and a minimum of $4^{\circ} \mathrm{C}$ in August (winter). Tidal amplitudes during spring and neap tides are 6.2 and $4.3 \mathrm{~m}$, respectively. Salinity shows minor variations around 33.4-33.7 psu, due to the absence of freshwater courses and the scarcity of precipitation in the area (Paruelo et al. 1998;
Bertness et al. 2006). Oceanographic surveys of San Jorge Gulf confirm this pattern for the coastal zone, where the extreme values recorded for 1999 and 2000 ranged between 33.1 and 33.8 psu (Fernández et al. 2005).

\section{Experimental design and sampling}

Artificial substrata were submersed in the harbour $4 \mathrm{~m}$ below mean low water and were never exposed to air during low tides in this study. They consisted of sixteen $20 \times 20 \times 0.4 \mathrm{~cm} \quad\left(400 \mathrm{~cm}^{2}\right) \quad$ low-density polyethylene panels screwed to four $1.6 \times 1 \mathrm{~m}$ horizontal supporting structures of galvanised iron lying approximately $10 \mathrm{~cm}$ above the bottom. Panels were roughened to make their surfaces more similar to those of natural substrata and to prevent the detachment of sessile organisms. Following Underwood and Anderson (1994), substrata were submersed simultaneously, but samples were taken independently with regard to time, that is, panels were not censused more than once. The study began in January 2004. Succession was analysed at quarterly intervals by randomly extracting four replicated panels (one from each supporting structure) at 3, 6, 9 and 12 months after starting the experiment (Fig. 1). In order to analyse the influence of seasonality on 1-year-old assemblages, three additional sets of four replicated panels were submersed in April (autumn), July (winter) and October (spring) and were collected 1 year later. Thus, a total of 28 panels were examined (7 submersion lengths/periods $\times 4$ replications, Fig. 1). During the collection of samples, each panel was placed in seawater within a zip-locked plastic bag to prevent the loss of organisms. Samples were then fixed in a solution of $4 \%$ formaldehyde in seawater and later preserved in $70 \%$ ethanol.

To avoid any border effect, only the central $10 \times 10 \mathrm{~cm}$ $\left(100 \mathrm{~cm}^{2}\right)$ of the upper and lower surfaces was analysed. Sessile organisms were identified to the lowest taxonomic level possible without disturbing their spatial distribution. Specimens occurring outside the central $100 \mathrm{~cm}^{2}$ were collected for taxonomic purposes. Coverage of each taxon was quantified by superposing a transparent plastic sheet with a grid of 100 evenly spaced points. The same grid point was counted twice whenever we detected a species covering other sessile species. Thus, total cover values higher than 100 were due to overlapping of organisms. Samples of biofilm scraped off the substratum and examined under microscope were found to be dominated by diatoms. Mobile organisms were also collected and identified, but are not dealt with in the present study.

Data analyses

The DIVERSE routine of the PRIMER package (Clarke and Warwick 2001) was used to calculate richness and the 
12

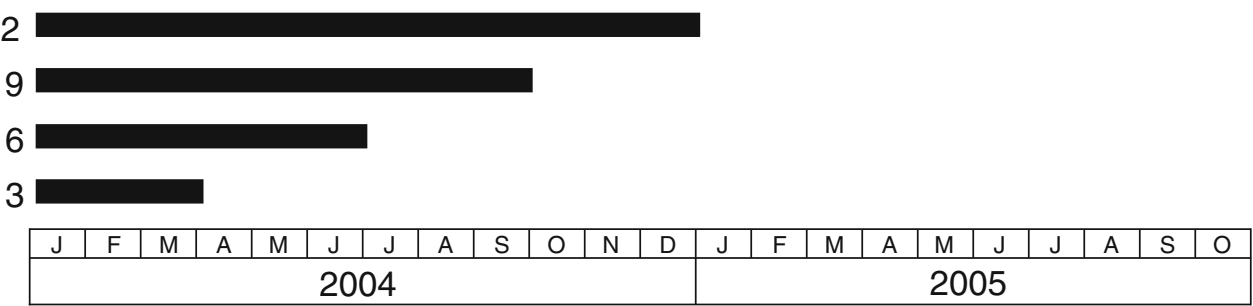

Fig. 1 Sampling scheme for the study of succession at Comodoro Rivadavia harbour. The submersion length (months) of each set of four replicated panels is indicated

Shannon diversity index (natural logarithms) of each sample. Changes in species richness and the Shannon index among different succession lengths or different sets of 1-year-old assemblages were analysed with two-way ANOVAs, with substratum orientation (two levels) and submersion length or starting season (four levels) as fixed factors. Homoscedasticity was verified with Cochran's C test (Underwood 1997). Species richness data had to be transformed using a logarithmic transformation $\left[\log _{10}(x+1)\right]$ to homogenise variances prior to ANOVA. Following Underwood (1997), when a significant interaction was found, means of one factor were compared separately at each level of the other factor with multiple a posteriori Student-Newman-Keuls (SNK) tests.

Coverage data were fourth-root transformed before multivariate analyses to downweight the influence of dominant taxa. A triangular similarity matrix was obtained applying the Bray-Curtis index. Similarities among samples obtained on upper and lower surfaces after different time intervals were analysed with non-Metric Multidimensional Scaling (nMDS) and Cluster Analysis using group average linkage. Clustering and ordination analyses were combined in the same plot to check the adequacy and mutual consistency of both representations (Clarke and Warwick 2001). Stress values $\leq 0.1$ correspond to a good ordination with no real prospect of a misleading interpretation (Clarke and Warwick 2001). Permutational multivariate analysis of variance (PERMANOVA, Anderson 2005) based on Bray-Curtis dissimilarities was used to analyse differences in assemblages. Factors were the same as those for the ANOVAs comparing species richness and the Shannon diversity index. Significance of $F$-ratios was determined from 999 randomisations of the data (Anderson 2005). As significant interactions were found (see "Results"), a posteriori comparisons for all possible pairwise combinations of submersion lengths/starting seasons were done separately for each level of the factor orientation (Anderson 2005).

\section{Results}

A total of 28 sessile animal and algal taxa were found during the entire study, 18 on the upper surfaces and 24 on the lower surfaces (Online Resource 1). Ascidians and bryozoans, the most diverse animal groups, were represented by 7 and 5 species, respectively. Lissoclinum fragile (Van Name), an invasive colonial ascidian known previously from Brazil (da Rocha et al. 2005), is here reported for the first time for Argentina.

An annual succession analysed at quarterly intervals

Species richness was significantly higher on lower than on upper surfaces analysed at quarterly intervals, but succession length had no significant effect on the number of species found on the panels (Fig. 2; Table 1).

A significant interaction between orientation and submersion length was found for the Shannon diversity index (Table 1), meaning that temporal changes in diversity depended on substratum orientation. This can be seen during the transition between 9 and 12 months, when the Shannon index decreased on the lower surfaces but not on the upper surfaces (Fig. 2). On the latter, all 6 pairwise contrasts between succession lengths were nonsignificant (SNK test, $P>0.05$ ). On the lower surfaces, however, the Shannon index was lowest in the 3-month assemblages and reached a maximum after 9 months of submersion (Fig. 2). Out of all possible pairwise comparisons, just the contrast between 3 and 9 months was significant (SNK test, $P=0.017$ ).

The analysis of multivariate data showed that succession brought about significant changes in assemblage structure on both surfaces. Cluster Analysis separated upper and lower surfaces in two groups at a similarity level of $24.2 \%$ (Fig. 3). The nMDS ordination showed that the assemblages on the lower surfaces were much more variable than 

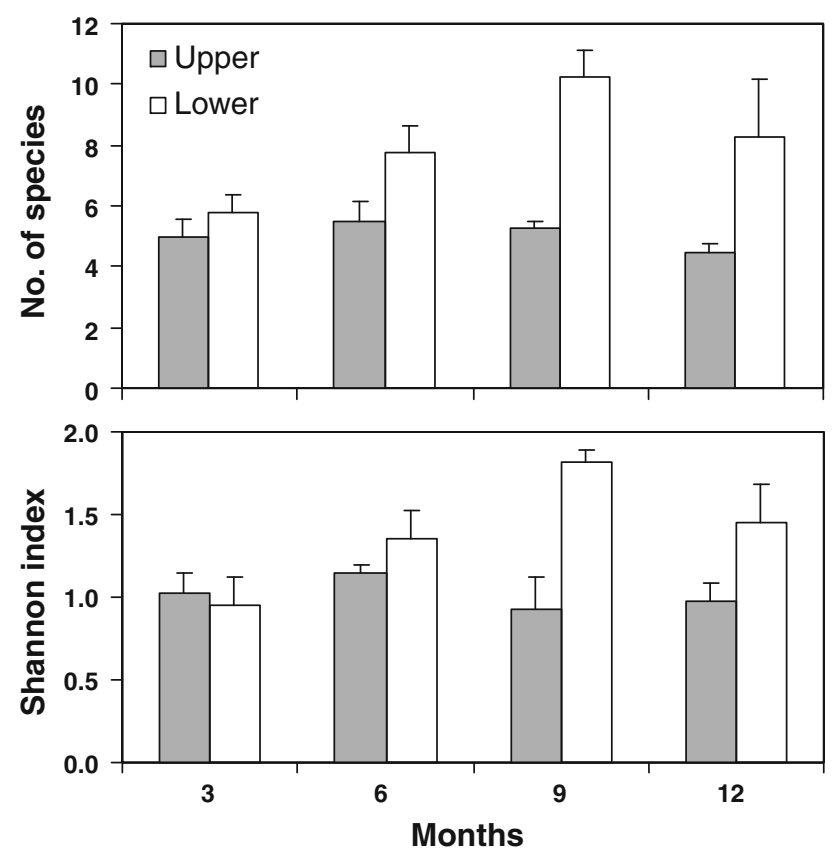

Fig. 2 Changes in species richness and the Shannon diversity index (mean $\pm \mathrm{SE}$ ) in fouling assemblages developed on upper and lower surfaces at 3, 6, 9 and 12 months after submersion

those on the upper surfaces. Few temporal patterns could be discerned in the ordination of assemblages developed on upper surfaces after different submersion lengths (Fig. 3). While the upper surfaces were dominated by ephemeral algae (Polysiphonia aff. abscissa, Ulva spp., Ectocarpus sp.), the lower surfaces showed high coverage of solitary and compound ascidians (Ascidiella aspersa, Diplosoma longinquum) and hydrozoans (Obelia sp.) (Fig. 4, Online Resource 1). On the lower surfaces, an abrupt decrease in coverage of two ascidians (Molgula manhattensis and D. longinquum) and their replacement by biofilm and the hydrozoan Obelia sp. were the most important changes observed during the transition between 9- and 12-month assemblages (Online Resource 1, Fig. 4). The decrease in diversity seen during the final period of the experiment (Fig. 2) may also be related to the dislodgment of these ascidians. In the nMDS ordination, 3-month assemblages appear clearly separated on the lower left side of the plot (Fig. 3). The species that best discriminated these assemblages from those developed on all the remaining substrata was the ascidian $D$. longinquum, which attained very high coverage values after just 3 months of succession (Fig. 4). A multivariate PERMANOVA test detected significant differences between surfaces and among submersion lengths (Table 2). The interaction between both factors was also significant, meaning that differences in assemblage structure among submersion lengths depended on surface orientation. On the upper surfaces, only the pairwise comparison between 3- and 9-month assemblages was signifi-
Table 1 Summary of two-way ANOVAs of the effect of substratum orientation and succession length or starting season on species richness and the Shannon diversity index

\begin{tabular}{|c|c|c|c|c|}
\hline Source & $d f$ & MS & $F$ & $P$ \\
\hline \multicolumn{5}{|l|}{$\begin{array}{l}\text { Succession analysed } \\
\text { at quarterly intervals }\end{array}$} \\
\hline \multicolumn{5}{|l|}{ Species richness ${ }^{\mathrm{a}}$} \\
\hline Surface orientation & 1 & 0.1994 & 22.0 & $<0.0001$ \\
\hline Succession length & 3 & 0.0219 & 2.4 & 0.09 \\
\hline $\begin{array}{l}\text { Surface orientation } \times \\
\text { succession length }\end{array}$ & 3 & 0.0152 & 1.7 & 0.20 \\
\hline Error & 24 & 0.0091 & & \\
\hline \multicolumn{5}{|l|}{ Shannon index } \\
\hline Surface orientation & 1 & 1.1256 & 12.2 & $<0.01$ \\
\hline Succession length & 3 & 0.2117 & 2.3 & 0.10 \\
\hline $\begin{array}{l}\text { Surface orientation } \times \\
\text { succession length }\end{array}$ & 3 & 0.3484 & 3.8 & 0.02 \\
\hline Error & 24 & 0.0920 & & \\
\hline \multicolumn{5}{|c|}{$\begin{array}{l}\text { 1-year-old assemblages } \\
\text { starting at different seasons }\end{array}$} \\
\hline \multicolumn{5}{|l|}{ Species richness ${ }^{\mathrm{a}}$} \\
\hline Surface orientation & 1 & 0.3360 & 34.4 & $<0.0001$ \\
\hline Starting season & 3 & 0.0026 & 0.3 & 0.85 \\
\hline $\begin{array}{l}\text { Surface orientation } \times \\
\text { starting season }\end{array}$ & 3 & 0.0192 & 2.0 & 0.15 \\
\hline Error & 24 & 0.0098 & & \\
\hline \multicolumn{5}{|l|}{ Shannon index } \\
\hline Surface orientation & 1 & 3.7725 & 58.2 & $<0.0001$ \\
\hline Starting season & 3 & 0.0612 & 0.9 & 0.44 \\
\hline $\begin{array}{l}\text { Surface orientation } \times \\
\text { starting season }\end{array}$ & 3 & 0.0486 & 0.7 & 0.53 \\
\hline Error & 24 & 0.0648 & & \\
\hline
\end{tabular}

Significant results in bold

$d f$ Degrees of freedom, $M S$ mean square, $F F$ ratio, $P$ probability values associated with $F$ values

a Log-transformed data

cant. On the lower surfaces, however, all pairwise contrasts showed significant differences in assemblage structure except for the comparison between 6 and 12 months (Table 2).

Effects of the seasonal onset on the successional outcome

Species richness and the Shannon diversity index were significantly higher on lower (surfaces) than on upper surfaces of 1-year-old assemblages, but no significant differences were found among assemblages that started in different seasons (Table 1; Fig. 5).

Cluster Analysis separated upper and lower surfaces in two groups at a similarity level of $27.6 \%$ (Fig. 6). As in the successions analysed at quarterly intervals, upper surfaces were dominated by algae and lower surfaces 


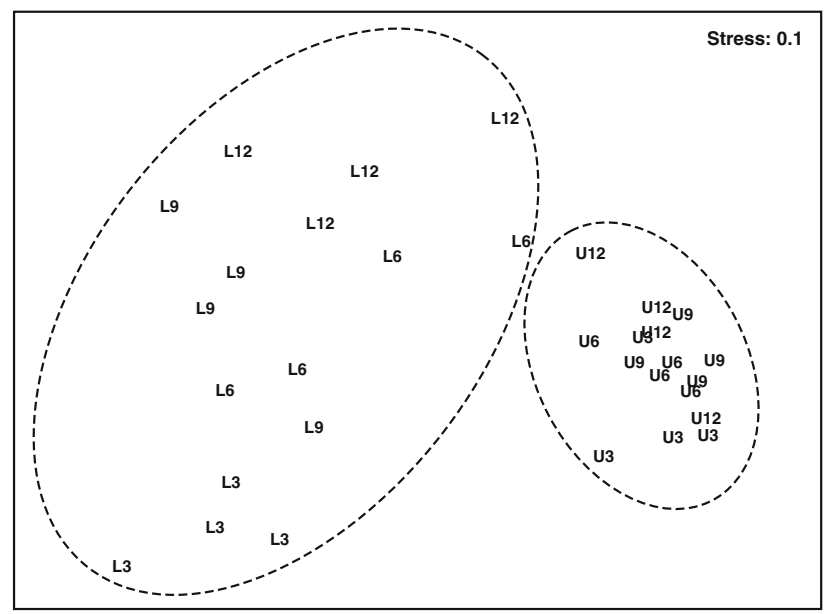

Fig. 3 nMDS ordinations of fouling assemblages developed on upper and lower surfaces at 3, 6,9 and 12 months after submersion. Dashed lines show the two largest groups obtained by Cluster Analysis at a similarity level of $24.2 \%$. $U$ upper, $L$ lower

showed high coverage of ascidians and hydrozoans (Fig. 4). On the upper surfaces, differences in structure were due to changes in the abundance of filamentous seaweeds or encrusting corallines (Fig. 4, Online Resource 1). Polysiphonia aff. abscissa was particularly abundant in 1-year-old assemblages starting in summer or in autumn, but scarce in those starting in winter or in spring (Fig. 4). The nMDS ordination showed again that the assemblages on the lower surfaces were more
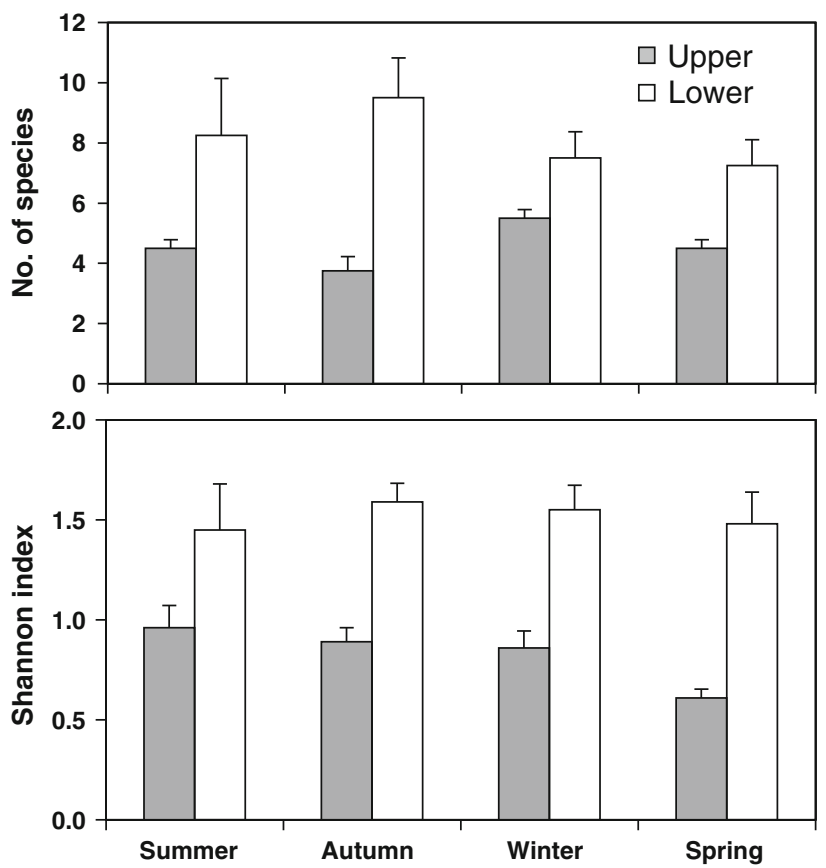

Fig. 5 Species richness and the Shannon diversity index (mean + SE) on upper and lower surfaces of 1-year-old assemblages starting at different seasons

variable than those on the upper surfaces (Fig. 6). On the lower surfaces, assemblages which started in autumn differed from those which began in summer, winter and spring by having high coverage values of the compound
Fig. 4 Bare substratum and coverage (mean $+\mathrm{SE})$ of dominant species on upper and lower surfaces at 3, 6, 9 and 12 months after submersion (left) and in 1-year-old assemblages starting at different seasons (right). Only species showing at least one mean coverage value $\geq 5 \%$ on upper surfaces or $\geq 20 \%$ on lower surfaces during this study were included (see Online Resource 1)
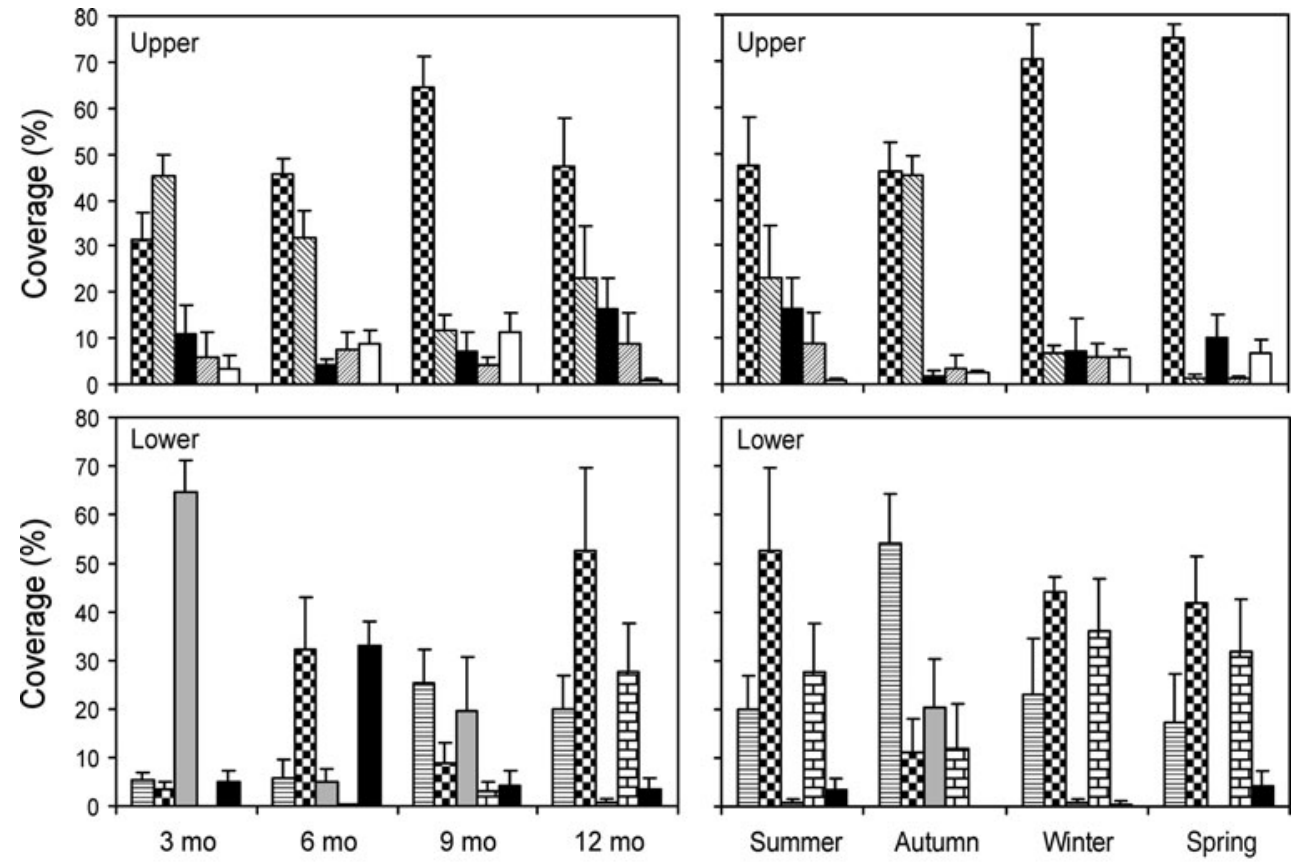

\begin{tabular}{|lll|}
\hline $\mathbf{B}$ Biofilm & $\square$ Ulva spp. & $\square$ Diplosoma longinquum \\
$\mathbb{Q}$ Polysiphonia aff. abscissa & $\square$ Ectocarpus sp. & 国 Obelia sp. \\
Bare substratum & 首 Ascidiella aspersa & \\
\hline
\end{tabular}


Table 2 Summary of multivariate PERMANOVAs of the effect of substratum orientation and succession length or starting season on assemblage structure

\begin{tabular}{|c|c|c|c|c|}
\hline \multicolumn{2}{|l|}{ Source } & MS & pseudo- $F$ & $P$ \\
\hline \multicolumn{5}{|c|}{$\begin{array}{l}\text { Succession analysed } \\
\quad \text { at quarterly intervals }\end{array}$} \\
\hline \multicolumn{2}{|l|}{ Surface orientation } & 27857.2 & 29.29 & 0.001 \\
\hline \multicolumn{2}{|l|}{ Succession length } & 4919.7 & 5.17 & 0.001 \\
\hline \multicolumn{2}{|c|}{$\begin{array}{l}\text { Surface orientation } \\
\quad \times \text { succession length }\end{array}$} & 4291.3 & 4.51 & 0.001 \\
\hline \multirow[t]{2}{*}{ Residual } & 24 & 951.2 & & \\
\hline & & \multicolumn{2}{|c|}{$t$} & $P$ \\
\hline \multicolumn{5}{|c|}{ Pairwise a posteriori comparisons } \\
\hline \multicolumn{5}{|l|}{ Lower surfaces } \\
\hline \multicolumn{2}{|c|}{3 months versus 6 months } & \multicolumn{2}{|c|}{2.74} & 0.012 \\
\hline \multicolumn{2}{|c|}{3 months versus 9 months } & \multicolumn{2}{|c|}{2.56} & 0.010 \\
\hline \multicolumn{2}{|c|}{3 months versus 12 months } & \multicolumn{2}{|c|}{3.92} & 0.002 \\
\hline \multicolumn{2}{|c|}{6 months versus 9 months } & \multicolumn{2}{|c|}{1.73} & 0.048 \\
\hline \multicolumn{2}{|c|}{6 months versus 12 months } & \multicolumn{2}{|c|}{1.48} & 0.124 \\
\hline \multicolumn{2}{|c|}{9 months versus 12 months } & \multicolumn{2}{|c|}{1.98} & 0.025 \\
\hline \multicolumn{5}{|l|}{ Upper surfaces } \\
\hline \multicolumn{2}{|c|}{3 months versus 6 months } & \multicolumn{2}{|c|}{1.68} & 0.080 \\
\hline \multicolumn{2}{|c|}{3 months versus 9 months } & \multicolumn{2}{|c|}{3.51} & 0.003 \\
\hline \multicolumn{2}{|c|}{3 months versus 12 months } & \multicolumn{2}{|c|}{1.54} & 0.130 \\
\hline \multicolumn{2}{|c|}{6 months versus 9 months } & \multicolumn{2}{|c|}{1.97} & 0.063 \\
\hline \multicolumn{2}{|c|}{6 months versus 12 months } & \multicolumn{2}{|c|}{1.01} & 0.374 \\
\hline 9 months versus 1 & nths & & .26 & 0.239 \\
\hline Source & $d f$ & MS & pseudo- $F$ & $P$ \\
\hline $\begin{array}{l}\text { 1-year-old assemblo } \\
\text { starting at differe }\end{array}$ & asons & & & \\
\hline Surface orientation & 1 & 23564.2 & 29.80 & 0.001 \\
\hline Starting season & 3 & 2572.3 & 3.25 & 0.008 \\
\hline $\begin{array}{l}\text { Surface orientation } \\
\times \text { starting season }\end{array}$ & 3 & 2265.4 & 2.86 & 0.009 \\
\hline Residual & 24 & 790.8 & & \\
\hline & & $t$ & & $P$ \\
\hline
\end{tabular}

Pairwise a posteriori comparisons

Lower surfaces

\begin{tabular}{lll} 
Summer versus autumn & 1.94 & $\mathbf{0 . 0 4 8}$ \\
Summer versus winter & 0.86 & 0.529 \\
Summer versus spring & 0.74 & 0.649 \\
Autumn versus winter & 2.15 & $\mathbf{0 . 0 2 6}$ \\
Autumn versus spring & 2.17 & $\mathbf{0 . 0 1 7}$ \\
Winter versus spring & 0.70 & 0.711 \\
Upper surfaces & & \\
Summer versus autumn & 1.30 & 0.219 \\
Summer versus winter & 1.42 & 0.144 \\
Summer versus spring & 1.98 & $\mathbf{0 . 0 3 9}$ \\
\hline
\end{tabular}

Table 2 continued

\begin{tabular}{lll}
\hline & $t$ & $P$ \\
\hline Autumn versus winter & 3.53 & $\mathbf{0 . 0 0 4}$ \\
Autumn versus spring & 5.30 & $\mathbf{0 . 0 0 2}$ \\
Winter versus spring & 1.24 & 0.211 \\
\hline
\end{tabular}

Significant results in bold

$d f$ Degrees of freedom, $M S$ mean square, $F F$ ratio, $P$ Monte Carlo probability values associated with $F$ values, $t$ multivariate version of the $t$-statistics (based on distances)

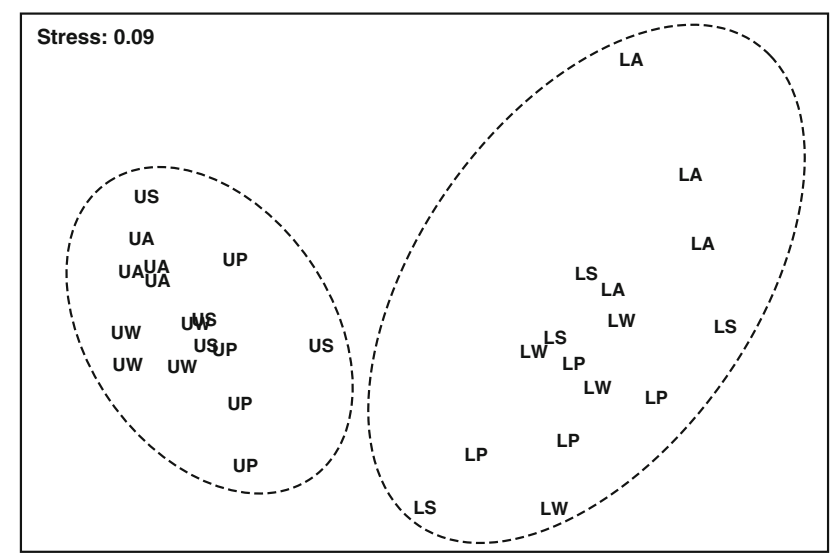

Fig. 6 nMDS ordinations of fouling assemblages developed on upper and lower surfaces in 1-year-old assemblages starting at different seasons. Dashed lines show the two largest groups obtained by Cluster Analysis at a similarity level of $27.6 \%$. $U$ upper, $L$ lower, $S$ summer, $A$ autumn, $W$ winter, $P$ spring

ascidian D. longinquum (Fig. 4). Again, the multivariate PERMANOVA test detected significant differences in assemblage structure between surfaces and among starting seasons (Table 2). The interaction between both factors was also significant, meaning that differences in assemblage structure among starting seasons depended on surface orientation. Three out of 6 pairwise contrasts showed significant differences in both upper and lower surfaces, but which of the contrasts were significant depended on surface orientation. On the upper surfaces, ephemeral algae such as Polysiphonia aff. abscissa seemed to be responsible for the significant contrasts involving 1-year-old assemblages which started in summer and autumn against those which started in winter and spring (Table 2). On the lower surfaces, however, only the pairwise contrasts involving 1-year-old assemblages starting in autumn showed significant differences against assemblages that began in other seasons, strongly suggesting that $D$. longinquum was the main species responsible for these significant changes in structure (Table 2; Fig. 4). 


\section{Discussion}

The results of this study show that the influence of seasonality on 1-year-old assemblages was modulated by substratum orientation. Downward-facing surfaces usually became dominated by solitary and colonial ascidians. Among other factors, high coverage of tunicates may be due to their great capacity for overgrowing other sessile organisms (Valdivia et al. 2005; Varfolomeeva et al. 2008; Claar et al. 2011) such as sponges, bryozoans and spirorbid polychaetes (Kay and Keough 1981). Seasonality was clearly important for determining the structure of 1-year-old assemblages on upper surfaces dominated by patches of fast-growing filamentous algae. Since differences between upward-oriented assemblages that started in different seasons were mainly due to ephemeral algae, the observed effect seems more influenced by the species that happened to be abundant during the last months before panel collection rather than to the early successional events that occurred just after the panels were deployed. San Jorge Gulf is characterised by a typical temperate seasonal cycle and significant temporal variation of the nutrient concentration in sediments (Fernández et al. 2005 , 2008). Thus, seasonality in algal growth is most likely related to seasonal variability of environmental conditions.

Seasonal aspects of recruitment and succession in an Australian intertidal estuarine fouling assemblage (Underwood and Anderson 1994) emphasised the importance of season of submersion on the successional process. The pattern of succession and the resultant structure of the assemblage reflected the unique history of stochastic events of larval settlement and invasion. An analysis of the effects of seasonality on an intertidal fouling assemblage in the Gulf of Mexico (Brown and Swearingen 1998) also showed that recruitment and successional patterns were heavily influenced by seasonal periodicities in adult reproduction and larval availability in the water column, without any unidirectional sequence of succession. Other studies found a high degree of initial variability, which decreased over time and gradually converged from different starting assemblages (Greene and Schoener 1982; Underwood and Chapman 2006; Cifuentes et al. 2010; Pacheco et al. 2011).

Solitary ascidians are often dominant competitors, occupying most available primary space in shallow-water fouling communities (e.g., Valdivia et al. 2005; Cifuentes et al. 2007). Our analysis of a fouling succession at quarterly intervals showed that a substantial proportion of the epifaunal assemblage was lost between 9 and 12 months after the beginning of the experiment, probably due to the weight gained by the ascidians. The next census after this event showed that primary space made available by the demise of the ascidians was occupied by fast-growing and rapidly spreading organisms such as biofilm and hydrozoans. The dislodgement of tunicates on lower surfaces of artificial substrata is a well-known phenomenon (e.g., Sutherland and Karlson 1977). In Comodoro Rivadavia, this catastrophic event was due at least in part to the presence of the alien tunicate $M$. manhattensis, whose coverage decreased one order of magnitude just before the succession attained 1 year. In Argentina, M. manhattensis is a nonindigenous species that previously had only been found in the fouling community of Mar del Plata harbour (Amor 1964; Bastida 1971). Paramolgula gregaria, another large and solitary ascidian, is a widespread Magellanic species (Kott 1969) that is very common in natural environments. It could be regarded as the native counterpart of $M$. manhattensis, but to our knowledge, it has not yet been found in Patagonian harbours. Another invasive solitary ascidian found in this assemblage, A. aspersa, appeared in several Argentine harbours since 1962 (Tatián et al. 2010) and is now one of the most conspicuous members of the fouling communities.

Previous studies reported that horizontal or vertical (Connell 1999; Glasby 2000; Glasby and Connell 2001; Irving and Connell 2002) as well as hidden or exposed (Pacheco et al. 2010a) surfaces usually support different epibiotic assemblages. Likewise, fouling assemblages on upper and lower surfaces of tiles deployed in Antarctica had little in common with each other (Stark 2008). In addition, the present study shows that the orientation of experimental surfaces immersed in a harbour was crucial in determining the composition and dynamics of their encrusting assemblages. Lower surfaces were mostly covered by filter-feeding invertebrates instead of algae, and underwent catastrophic events due to the detachment of solitary and colonial ascidians. Therefore, constancy or variability in the result of annual successions whose development began at different seasons depended greatly on the life history of the organisms that settled and managed to persist on both surfaces, which in turn depended on substratum orientation.

Acknowledgments We are grateful to Consejo Nacional de Investigaciones Científicas y Técnicas (CONICET) for financial support (PIP No. 0291 to JLG), to Walter Mazza and Centro Argentino de Datos Oceanográficos (CEADO) for providing sea surface temperatures of Comodoro Rivadavia, and to Prefectura Naval Argentina, Horacio It and Gringo Durbas for logistic support and SCUBA diving. An earlier version of the manuscript benefitted greatly from constructive comments by Martin Thiel and four anonymous reviewers. Thanks to Marcos Tatián, Cristian Lagger and Mercedes Varela for the identification of the ascidians. The egg masses of Helcogrammoides cunninghami were identified by Atila Gosztonyi.

\section{References}

Amor A (1964) Ascidias nuevas para la fauna argentina. Physis 24:351 Anderson MJ (2005) PERMANOVA: a FORTRAN computer program for permutational multivariate analysis of variance. Department of Statistics, University of Auckland, New Zealand 
Bastida R (1971) Las incrustaciones biológicas en el puerto de Mar del Plata. Período 1966/67. Rev Mus Argent Cienc Nat Bernardino Rivadavia Inst Nac Invest Cienc Nat (Argent), Hidrobiol 3:203285

Bertness MD, Crain CM, Silliman BR, Bazterrica MC, Reyna MV, Hidalgo F, Farina JK (2006) The community structure of western Atlantic Patagonian rocky shores. Ecol Monogr 76:439-460

Breitburg DL (1985) Development of a subtidal epibenthic community: factors affecting species composition and the mechanisms of succession. Oecologia 65:173-184

Brown KM, Swearingen DC (1998) Effects of seasonality, length of immersion, locality and predation on an intertidal fouling assemblage in the Northern Gulf of Mexico. J Exp Mar Biol Ecol 225:107-121

Chalmer PN (1982) Settlement patterns of species in a marine fouling community and some mechanisms of succession. J Exp Mar Biol Ecol 58:73-85

Cifuentes M, Kamlah C, Thiel M, Lenz M, Wahl M (2007) Effects of temporal variability of disturbance on the succession in marine fouling communities in northern-central Chile. J Exp Mar Biol Ecol 352:280-294

Cifuentes M, Krueger I, Dumont CP, Lenz M, Thiel M (2010) Does primary colonization or community structure determine the succession of fouling communities? J Exp Mar Biol Ecol 395:10-20

Claar DC, Edwards KF, Stachowicz JJ (2011) Positive and negative effects of a dominant competitor on the settlement, growth, and survival of competing species in an epibenthic community. J Exp Mar Biol Ecol 399:130-134

Clarke KR, Warwick RM (2001) Change in marine communities: an approach to statistical analyses and interpretation, 2nd edn. PRIMER-E Ltd, Plymouth

Connell SD (1999) Effects of surface orientation on the cover of epibiota. Biofouling 14:219-226

Connell JH, Slatyer RO (1977) Mechanisms of succession in natural communities and their role in community stability and organization. Am Nat 111:1119-1144

da Rocha RM, Moreno TR, Metri R (2005) Ascídias (Tunicata, Ascidiacea) da Reserva Biológica Marinha do Arvoredo, Santa Catarina, Brasil. Rev Bras Zool 22:461-476

Dean TA, Hurd LE (1980) Development in an estuarine fouling community: the influence of early colonists on later arrivals. Oecologia 46:295-301

Farrell TM, Bracher D, Roughgarden J (1991) Cross-shelf transport causes recruitment to intertidal populations in central California. Limnol Oceanogr 36:279-288

Fernández M, Carreto JI, Mora J, Roux A (2005) Physico-chemical characterization of the benthic environment of the Golfo San Jorge, Argentina. J Mar Biol Assoc UK 85:1317-1328

Fernández M, Mora J, Roux A, Cucchi Colleoni DA, Gasparoni JC (2008) New contribution on spatial and seasonal variability of environmental conditions of the Golfo San Jorge benthic system, Argentina. J Mar Biol Assoc UK 88:227-236

Gaines S, Roughgarden J (1985) Larval settlement rate: a leading determinant of structure in an ecological community of the marine intertidal zone. Proc Natl Acad Sci USA 82:3707-3711

Glasby TM (2000) Surface composition and orientation interact to affect subtidal epibiota. J Exp Mar Biol Ecol 248:177-190

Glasby TM, Connell SD (2001) Orientation and position of substrata have large effects on epibiotic assemblages. Mar Ecol Prog Ser 214:127-135

Greene CH, Schoener A (1982) Succession on marine hard substrata: a fixed lottery. Oecologia 55:289-297

Irving AD, Connell SD (2002) Sedimentation and light penetration interact to maintain heterogeneity of subtidal habitats: algal versus invertebrate dominated assemblages. Mar Ecol Prog Ser 245:83-91
Kay AM, Keough MJ (1981) Occupation of patches in the epifaunal communities on pier pilings and the bivalve Pinna bicolor at Edithburgh, South Australia. Oecologia 48:123-130

Kott P (1969) Antarctic Ascidiacea. Antarct Res Ser 13:1-239

Littler MM, Murray SN (1974) The primary productivity of marine macrophytes from a rocky intertidal community. Mar Biol 27:131-135

McCook LJ (1994) Understanding ecological community succession: causal models and theories, a review. Vegetatio 110:115-147

Osman RW (1977) The establishment and development of a marine epifaunal community. Ecol Monogr 47:37-63

Pacheco AS, Laudien J, Thiel M, Heilmayer O, Oliva M (2010a) Hardbottom succession of subtidal epibenthic communities colonizing hidden and exposed surfaces off northern Chile. Sci Mar 74:147-154

Pacheco AS, Laudien J, Thiel M, Oliva M, Arntz W (2010b) Succession and seasonal variation in the development of subtidal macrobenthic soft-bottom communities off northern Chile. J Sea Res 64:180-189

Pacheco AS, Laudien J, Thiel M, Oliva M, Heilmayer O (2011) Succession and seasonal onset of colonization in subtidal hardbottom communities off northern Chile. Mar Ecol 32:75-87

Paruelo JM, Beltrán A, Jobbágy E, Sala OE, Golluscio RA (1998) The climate of Patagonia: general patterns and controls on biotic processes. Ecol Austral 8:85-101

Rico A, Peralta R, López Gappa J (2010) Recruitment variation in subtidal macrofouling assemblages of a Patagonian harbour (Argentina, SW Atlantic). J Mar Biol Assoc UK 90:437-443

Stark JS (2008) Patterns of higher taxon colonisation and development in sessile marine benthic assemblages at Casey Station, Antarctica, and their use in environmental monitoring. Mar Ecol Prog Ser 365:77-89

Steneck RS, Dethier MN (1994) A functional group approach to the structure of algal-dominated communities. Oikos 69:476-498

Sutherland JP (1974) Multiple stable points in natural communities. Am Nat 108:859-873

Sutherland JP, Karlson RH (1977) Development and stability of the fouling community at Beaufort, North Carolina. Ecol Monogr 47:425-446

Tatián M, Schwindt E, Lagger C, Varela MM (2010) Colonization of Patagonian harbours (SW Atlantic) by an invasive sea squirt. Spixiana 33:111-117

Turner T (1983) Facilitation as a successional mechanism in a rocky intertidal community. Am Nat 121:729-738

Turner SJ, Todd CD (1993) The early development of epifaunal assemblages on artificial substrata at two intertidal sites on an exposed rocky shore in St. Andrews Bay, N.E. Scotland. J Exp Mar Biol Ecol 166:251-272

Underwood AJ (1997) Experiments in ecology. Their logical design and interpretation using analysis of variance. Cambridge University Press, Cambridge

Underwood AJ, Anderson MJ (1994) Seasonal and temporal aspects of recruitment and succession in an intertidal estuarine fouling assemblage. J Mar Biol Assoc UK 74:563-584

Underwood AJ, Chapman MG (2006) Early development of subtidal macrofaunal assemblages: relationships to period and timing of colonization. J Exp Mar Biol Ecol 330:221-233

Underwood AJ, Denley EJ (1984) Paradigms, explanations, and generalizations in models for the structure of intertidal communities on rocky shores. In: Strong DR, Simberfoff D, Abele LG, Thistle $\mathrm{AB}$ (eds) Ecological communities: conceptual issues and the evidence. Princeton University Press, Princeton, pp 151-180

Valdivia N, Heidemann A, Thiel M, Molis M, Wahl M (2005) Effects of disturbance on the diversity of hard-bottom macrobenthic communities on the coast of Chile. Mar Ecol Prog Ser 299:45-54

Varfolomeeva M, Artemieva A, Shunatova N, Yakovis E (2008) Growth and survival of barnacles in presence of co-dominating solitary ascidians: growth ring analysis. J Exp Mar Biol Ecol 363:42-47 